\title{
Description and Validation of the Moorepark Dairy System Model
}

\author{
L. Shalloo, ${ }^{1,2}$ P. Dillon, ${ }^{1}$ M. Rath, ${ }^{3}$ and M. Wallace ${ }^{2}$ \\ ${ }^{1}$ Dairy Production Department, Teagasc, \\ Moorepark Production Research Centre, \\ Fermoy, Co. Cork, Ireland \\ ${ }^{2}$ Department of Agribusiness, Extension and Rural Development, \\ Faculty of Agriculture, University College Dublin, \\ Belfield, Dublin 4, Ireland \\ ${ }^{3}$ Department of Animal Science, Faculty of Agriculture, \\ University College Dublin, \\ Belfield, Dublin 4, Ireland
}

\section{ABSTRACT}

A stochastic budgetary simulation model of a dairy farm was developed to allow investigation of the effects of varying biological, technical, and physical processes on farm profitability. The model integrates animal inventory and valuation, milk supply, feed requirement, land and labor utilization, and economic analysis. A key model output is the estimated distribution of farm profitability, which is a function of total receipts from milk, calves, and cull cows less all variable and fixed costs (including an imputed cost for labor). An application of the model was demonstrated by modeling 2 calving patterns: a mean calving date of February 24 (S1) and a mean calving date of January 27 (S2). Monte Carlo simulation was used to determine the influence of variation in milk price, concentrate cost, and silage quality on farm profitability under each scenario. Model validation was conducted by comparing the results from the model against data collected from 21 commercial dairy farms. The net farm profit with $\mathrm{S} 1$ was $€ 53,547$, and that with S2 was €51,687; the annual EU milk quota was $468,000 \mathrm{~kg}$, and farm size was 40 ha. Monte Carlo simulation showed that the $\mathrm{S} 1$ scenario was stochastically dominant over the S2 scenario. Sensitivity analyses showed that farm profit was most sensitive to changes in milk price. The partial coefficients of determination were $99.2,0.7$, and $0.1 \%$ for milk price, concentrate cost, and silage quality, respectively, in $\mathrm{S} 1$; the corresponding values in S2 were 97.6, 2.3, and 0.1\%. Validations of the model showed that it could be used with confidence to study systems of milk production under Irish conditions.

(Key words: whole-farm stochastic budgeting, Monte Carlo simulation, milk production system)

Received July 23, 2003.

Accepted November 26, 2003.

Corresponding author: L. Shalloo; e-mail: lshalloo@moorepark. teagasc.ie.

\begin{abstract}
Abbreviation key: CDF = cumulative probability distribution function, CSO $=$ Central Statistics Office, DairyMIS = dairy management information system, MDSM = Moorepark Dairy System Model, $\mathbf{N E}=$ net energy, $\mathbf{S 1}=$ mean calving date February $24, \mathbf{S} 2=$ mean calving date January 27.
\end{abstract}

\section{INTRODUCTION}

Dairy farmers face important issues related to improving efficiency, lowering costs, and increasing productivity while being cognizant of issues related to the environment, animal welfare, and food safety. The complex interrelationship between a large number of factors in a dairy system makes it difficult to determine the costs and benefits of implementing various management or technological alternatives. Mathematical models are increasingly being used in animal research both independently and in conjunction with experimental research (Bywater and Cacho, 1994). Farm simulation models can make a major contribution to guiding experimental research in a variety of ways. These range from identification of critical gaps in knowledge or data to interpretation of experimental results and the development of improved systems of production (Bywater and Cacho, 1994). Farm simulation models also have a role as direct extension and management tools (i.e., evaluating alternative systems).

Three uses of models have been identified in animal research: component, system, and management research modeling. Modeling factors controlling digestion, metabolism, and production of animals (Neal and Thornley, 1983; Baldwin et al., 1987) are examples of component research modeling. The use of models in system research is aimed at characterizing and understanding the interactions that occur between components at the production system level. Examples of such models found in grazing research include investigating the interaction between the grazing animal and pasture production (Parsons et al., 1983; Korte et al., 1984). 
Management models are normally used to investigate the effects of short- and long-term management options on output (production, returns, and risk) of the system. Examples of such models are the dairy system simulation model (Rotz et al., 1989), the Texas A\&M sheep simulation model (Blackburn and Cartwright, 1987), and the deterministic static linear model (Berentsen and Giesen, 1995).

Mathematical models in agricultural systems use 2 general techniques: simulation or optimization. Simulation models of agricultural systems are developed to accurately describe the evolution of the systems. It can be argued that simulation models lack the creditability of field experiments (McCall, 1993), but that they provide the opportunity to explore difficult relationships that cannot be explored in any other way. They allow examination with a far greater range of variables over a much wider range of conditions than is feasible in practice, e.g., analysis of factors affecting wool production in Victoria, New Zealand (Bowman, 1989). A welldesigned model can simulate various outcomes, allowing the study of their probability distribution using stochastic simulation (Swinton and Black, 2000). Optimization models seek to optimize some criterion or set of criteria subject to a set of constraints. Optimization models can support the decision-making objectives of agricultural managers, such as minimizing the cost of animal weight gain, enhancing weed control, or boosting farm profits (King et al., 1993). Optimization models are generally developed for a specific situation and are, therefore, less suited to study the consequences of a wide range of management strategies (Jalvingh et al., 1992). This present model was constructed to allow investigation of the effects of varying biological, technical, and physical processes on farm profitability; therefore, a simulation model was considered most appropriate.

A number of agricultural system models have been developed (Richardson and Nixon, 1986; Rotz et al., 1989; Milham, 1992; Berentsen and Giesen, 1995; McCall et al., 1999). Richardson and Nixon (1986) developed a stochastic whole-farm budgeting model (FLIPSIM), which simulated, under price and yield risk, the annual economic activities of a representative farm. Rotz et al. (1989) developed the dairy forage system model (DAFOSYM) to evaluate technologies and management strategies on representative dairy farms. Milham (1992) developed a stochastic whole-farm budgeting system, RISKFARM, to enable the appraisal of the financial performance and risk effects of alternative farm and non-farm investment of Australian farms. Berentsen and Giesen (1995) developed a deterministic static linear programming model of a dairy farm to determine the effect of institutional, technical, and price changes on a farm plan, economic results, and nutrient losses to the environment. McCall et al. (1999) developed a linear programming model to determine the optimum feeding strategies for dairy systems in both the Northern US and New Zealand.

The rationale for the development of the present farm simulation model was to be able to examine aspects of seasonal grass-based systems of production using minimal concentrate. Alternative management strategies and the use of different breeds or strains under varying feeding regimens have been evaluated (Dillon et al., 1995; Buckley et al., 2000; Kennedy et al., 2002; Dillon et al., 2003). Computer simulation is an approach that can help in the planning, interpretation, and analysis of such studies. There are 3 objectives in this paper. The first is to describe the Moorepark Dairy System Model (MDSM). The unique aspect of this model is the use of budgetary simulation and stochastic modeling of a milk production system. The budgetary simulation incorporates the many biological (milk yield and composition, BW, nutritional requirement, fertilizer), physical (land, labor, buildings), and economic (costs, valuations, profit and loss account, balance sheet) processes on a typical dairy farm. Stochastic budgeting, using Monte Carlo simulation, is used to determine the influence of variation in milk price, concentrate costs, and silage quality on farm profitability. The second objective is to validate the model by comparing both the physical and financial performance of a sample of dairy farms to the outputs from the model. Finally, the third objective is to demonstrate an application of the model using 2 calving patterns.

\section{MATERIALS AND METHODS}

\section{Bioeconomic Model}

The model in this paper is an enhancement of a deterministic whole-farm budgeting model, formulated in an Excel spreadsheet. Simulation of herd performance was based on groups of cows calving in the middle of February, March, and April; within these groups no allowances were made for different age or lactation classes. The financial reports are derived from equations linking the farm receipts, costs, and capital investment. Figure 1 shows a schematic diagram of the MDSM. The model was simulated over a 12 -mo period. The dairy herd was broken down by month of calving. The worksheet displays the following information for each month of calving over the $12 \mathrm{mo}$ : livestock movement (culling, purchases, and sales) at the start and end of each month, livestock valuations (cows, male and female calves, and male and female yearlings) at the start and end of each month, expected milk production, and feed requirement. Details of the simulation model are described subsequently. The case farm used in this study 


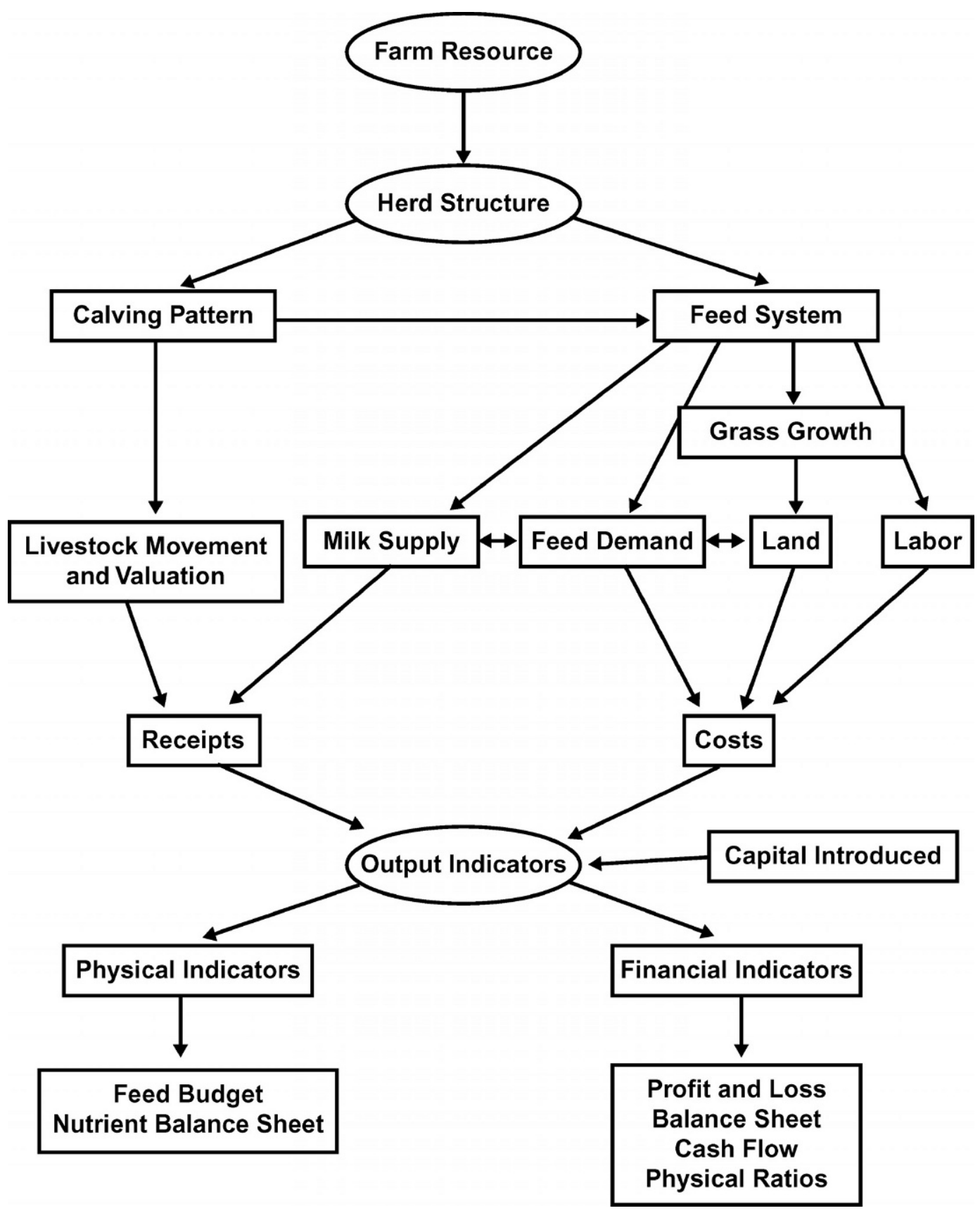

Figure 1. Flow chart of the Moorepark Dairy Systems Model illustrating the major components of the model and their interrelationships.

was 40 ha in size with a 468,000-kg EU annual milk quota, which limits the amount of milk that can be sold from the farm. The soil type was considered a freedraining acid brown earth of sandy loam to loam texture. Ireland enjoys a favorable climate for grassland farming, with winter temperatures high enough to allow some grass growth and relatively high summer rainfall (i.e., serious drought is not common). The basic element of the MDSM is the dairy cow.
Calving pattern and feed system. In the default scenario (S1; mean calving date is February 24) the calving interval was $365 \mathrm{~d}$ with 70,20 , and $10 \%$ of the cows calving in February, March, and April, respectively. To achieve this, breeding started on a fixed calendar date in late April. Once breeding was started, every cow detected in estrous was served using AI, regardless of number of days since calving. The key objective was to achieve to the highest pregnancy rate in the shortest 
period of time. The breeding season was confined to $13 \mathrm{wk}$, which resulted in a mean herd calving date of February 24 with $89 \mathrm{~d}$ spread across calving (February 1 to April 30).

This milk production system was spring calving grass-based (Dillon et al., 1995; Kennedy et al., 2002), which is representative of the production system on most Irish dairy farms. It is very dependent on the efficient utilization of grazed grass (Stakelum, 1991). Calving date is targeted to commence at the start of the grass-growing season. The objective of the system is to optimize grazed grass as a proportion of the total diet of the lactating dairy cow, allowing high cow performance while, at the same time, minimizing the cost of milk production. Feeding and management were based on current best practices in seasonal spring calving pasture-based systems (O'Donovan, 2000). The proportion of feeds offered (grass, grass silage, and concentrate) was altered to meet the net energy (NE) requirement for milk production, maintenance, and BW change (Jarrige, 1989). A fixed feeding system was used for young stock as per Teagasc guidelines (Teagasc, 2002).

Livestock movement and valuation. The model displays the number of cows at the start and the end of each month and the number of cows culled (Table 1). It was assumed that cows were dried off at 2 mo before the next calving, and replacements were introduced as in-calf 2-yr-old heifers to replace culled and dead cows. The culling percentages (voluntary plus involuntary) per month of lactation used in the model were $1.46,1.31,1.03,2.34,0.50,0.05,0.92,0.63,0.83$, $1.16,5.37$, and $3.26 \%$ for mo 1 to 12 , respectively, and similar to that being obtained in Irish spring calving dairy herds (Crosse, 1986). These culling rates resulted in $20 \%$ of cows being replaced each year. The model also displays the purchases and sales of livestock in each month. The valuation of cows and other livestock is also calculated at the start and the end of each month.

The model assumed that $45 \%$ of the female calves were reared for replacements, but these animals were sold for $€ 1206$ at 23 mo of age. It was assumed that these replacements were purchased for the same price, in fixed proportions, 70, 20, and 10\%, in February, March, and April, respectively. This simulates the practice among dairy farmers to consider young stock rearing as a separate enterprise; it also allows for the flexibility at farm level to sell surplus replacements, which, for example, calve at a more suitable time. All male and surplus female calves were sold at 1 mo of age. Therefore, MDSM allows the flexibility to consider rearing replacements as a separate enterprise or part of the dairy enterprise, depending on the sale date of young stock.
Milk supply. Annual milk production averaged 6421 $\mathrm{kg}$ per cow with $38.6 \mathrm{~g} / \mathrm{kg}$ fat, $34.0 \mathrm{~g} / \mathrm{kg}$ protein, and $46.6 \mathrm{~g} / \mathrm{kg}$ lactose; the stocking rate was 2.35 cows $/$ ha. The lactation curves for milk yield and milk composition were based on the results of a 3-yr (1998-2000) farm study carried out at Moorepark (Kennedy et al., 2002). The lactation curves for milk yield, as affected by calving date, were obtained from Irish spring calving herds (Crosse, 1986), with no random variation. Milk yield and milk composition were modeled for an average group for each month of calving rather than for individual cows. Similarly, the average BW and BW change for milking cows during lactation were also calculated from the Moorepark farm study.

Feed demand. The feeding regimen modeled had fixed ratios of grazed grass, grass silage, and concentrate for each month of the year for the 3 mo of calving. These ratios were not influenced by milk yield, but the amount of feed offered was altered to meet the $\mathrm{NE}$ system (Jarrige, 1989). The NE content of concentrate was determined using the feed unit for lactation (UFL) content of the ingredients (O'Mara, 1996). The NE values of the silage were related to the in vitro DM digestibility. The NE content of the herbage was related to its chemical composition (Jarrige, 1989). The following equations were used to determine the energy required for maintenance, pregnancy, and energy output in milk.

Energy required for maintenance:

$$
\mathrm{UFL} / \mathrm{d}=[(1.4+0.6(\mathrm{BW} / 100)] \times \mathrm{AA} ;
$$

Energy required for pregnancy:

$$
\begin{aligned}
\mathrm{UFL} / \mathrm{d}= & 0.00075 \times \mathrm{BWC} \times \operatorname{EXP}(0.0165) \\
& \times(286-\mathrm{DBC}) ; \text { and }
\end{aligned}
$$

Energy required for milk output:

$$
\begin{gathered}
\mathrm{UFL} / \mathrm{kg} \mathrm{milk}=0.0054 \mathrm{FC}+0.0031 \mathrm{PC} \\
+0.0028 \mathrm{LC}-0.015
\end{gathered}
$$

where $\mathrm{AA}=$ activity allowance based on an increase of $10 \%$ when cows are indoors and $20 \%$ when on pasture; $\mathrm{BWC}=\mathrm{BW}$ of calf at calving (assumed to be $40 \mathrm{~kg}$ ); $\mathrm{DBC}=$ days before calving; and $\mathrm{FC}, \mathrm{PC}$, and $\mathrm{LC}=$ milk fat, protein, and lactose content $(\mathrm{g} / \mathrm{kg})$, respectively.

A correction factor was added to the energy requirement based on the proportion of concentrate in the dietary DM:

$$
\Delta \mathrm{NE}=6.3(\mathrm{PrC})^{2}+0.02(\mathrm{NEI})^{2}-0.017(\mathrm{NEI})
$$

where $\Delta \mathrm{NE}=\mathrm{NE}$ requirements corrected for the proportion of concentrate in the diet, $\mathrm{PrC}=$ proportion of concentrate in diet, and NEI $=$ NE intake. 
Table 1. Default herd parameters for a 365-d period.

\begin{tabular}{|c|c|c|c|c|c|c|c|c|c|c|c|c|c|}
\hline & Jan & Feb & Mar & Apr & May & Jun & Jul & Aug & Sep & Oct & Nov & Dec & Total \\
\hline \multicolumn{14}{|l|}{ Animals present } \\
\hline Total cows & 75.6 & 77.0 & 77.0 & 75.7 & 74.0 & 73.0 & 72.5 & 71.9 & 71.4 & 70.7 & 69.9 & 67.0 & - \\
\hline Cows milking & 20.1 & 61.1 & 69.0 & 75.7 & 74.0 & 73.0 & 72.5 & 71.9 & 71.4 & 70.7 & 69.9 & 67.0 & - \\
\hline Cows dry & 46.1 & 13.2 & 6.6 & - & - & - & - & - & - & - & - & - & - \\
\hline Cows calving & - & 44.5 & 12.8 & 6.3 & - & - & - & - & - & - & - & - & 63.6 \\
\hline Replacements calving & - & 11 & 3.1 & 1.6 & - & - & - & - & - & - & - & - & 15.7 \\
\hline Cows dried & 13.2 & 6.6 & - & - & - & - & - & - & - & - & - & 46.1 & 65.9 \\
\hline Calves & 16.9 & 58.9 & 29.2 & 23.2 & 17.2 & 17.2 & 17.2 & 17.1 & 17.1 & 17.1 & 17.0 & 17.0 & - \\
\hline Yearlings & 5.0 & 13.5 & 15.2 & 16.9 & 16.9 & 16.9 & 16.8 & 16.8 & 16.8 & 16.8 & 16.8 & 16.8 & 15.4 \\
\hline \multicolumn{14}{|l|}{ Animal sales and purchases } \\
\hline Cows died & 0.0 & 0.1 & 0.2 & 0.2 & 0.1 & 0.2 & 0.1 & 0.1 & 0.1 & 0.0 & 0.0 & 0.0 & 1.2 \\
\hline Cows culled & 2.4 & 1.7 & 1.4 & 1.1 & 1.6 & 0.8 & 0.4 & 0.6 & 0.5 & 0.6 & 0.8 & 2.9 & 14.5 \\
\hline Male calves sold & - & - & 26.9 & 7.7 & 3.8 & - & - & - & - & - & - & - & 38.4 \\
\hline Female calves sold & - & - & 14.8 & 4.2 & 2.1 & - & - & - & - & - & - & - & 21.1 \\
\hline Replacements purchased & 11.0 & 3.1 & 1.6 & - & - & - & - & - & - & - & - & - & 15.7 \\
\hline \multicolumn{14}{|l|}{ Milk production } \\
\hline Milk produced, kg & 2747 & 14,914 & 38,168 & 60,961 & 63,291 & 58,633 & 53,983 & 50,043 & 44,475 & 38,550 & 26,872 & 9985 & 462,622 \\
\hline Milk fed to calves, $\mathrm{kg}$ & - & 6461 & 5594 & 1959 & 518 & 52 & - & - & - & - & - & - & 14,584 \\
\hline Fat sales, kg & 116 & 353 & 1310 & 2253 & 2309 & 2130 & 1963 & 1882 & 1747 & 1585 & 1124 & 421 & 17,191 \\
\hline Protein sales, kg & 100 & 283 & 1053 & 1940 & 2068 & 1940 & 1800 & 1717 & 1597 & 1414 & 982 & 363 & 15,255 \\
\hline \multicolumn{14}{|l|}{ Milk supply profile } \\
\hline Milk, \% & 0.59 & 3.22 & 8.25 & 13.18 & 13.68 & 12.67 & 11.67 & 10.82 & 9.61 & 8.33 & 5.81 & 2.16 & 100 \\
\hline Fat concentration, $\%$ & 4.22 & 4.17 & 4.02 & 3.82 & 3.68 & 3.64 & 3.64 & 3.76 & 3.93 & 4.11 & 4.18 & 4.22 & - \\
\hline Protein concentration, \% & 3.60 & 3.34 & 3.23 & 3.29 & 3.29 & 3.31 & 3.33 & 3.43 & 3.59 & 3.67 & 3.65 & 3.63 & - \\
\hline \multicolumn{14}{|l|}{ Feed requirements } \\
\hline $\begin{array}{l}\text { Demand grass, } \mathrm{kg} \text { of } \mathrm{DM} / \mathrm{d} \\
\text { per cow }\end{array}$ & - & 1.9 & 5.4 & 10.4 & 15.9 & 16.1 & 15.8 & 15.7 & 15.2 & 13.8 & 7.1 & 0.4 & - \\
\hline $\begin{array}{l}\text { Demand silage, } \mathrm{kg} \text { of } \mathrm{DM} / \mathrm{d} \\
\text { per cow }\end{array}$ & 10.4 & 7.3 & 3.3 & 1.4 & - & - & - & - & - & 0.9 & 5.8 & 10.6 & - \\
\hline Demand concentrate, $\mathrm{kg}$ & 0.3 & 20 & 41 & 35 & 01 & - & - & - & - & 02 & 0.7 & 07 & - \\
\hline Total demand, $\mathrm{kg}$ of $\mathrm{DM} / \mathrm{d}$ & 107 & 112 & 128 & 153 & 160 & 161 & 158 & 157 & 152 & 149 & 136 & 116 & 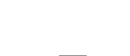 \\
\hline Grazing cover $>4 \mathrm{~cm}, \mathrm{~kg}$ & & & & & & & & & & 14.9 & 10.0 & 11.0 & \\
\hline of DM/ha & 700 & 642 & 760 & 867 & 965 & 901 & 980 & 982 & 1074 & 750 & 434 & 550 & - \\
\hline \multicolumn{14}{|l|}{ Land use } \\
\hline Area closed for silage, ha & - & - & 15.2 & 15.2 & 15.2 & 10.1 & 10.1 & 10.1 & - & - & - & - & - \\
\hline $\begin{array}{l}\text { Area available for } \\
\text { grazing, ha }\end{array}$ & 37.9 & 37.9 & 22.7 & 22.7 & 22.7 & 27.8 & 27.8 & 27.8 & 37.9 & 37.9 & 37.9 & 37.9 & - \\
\hline Area cut for silage, ha & - & - & - & - & 15.2 & - & - & 10.1 & - & - & - & - & - \\
\hline $\begin{array}{l}\text { Grass growth utilized, } \\
\text { kg/DM }\end{array}$ & - & 48.3 & 481.0 & 1393.3 & 1990.3 & 1741.6 & 1876.5 & 1587.0 & 1166.3 & 644.2 & 127.5 & - & 11,056 \\
\hline \multicolumn{14}{|l|}{ Labor requirements } \\
\hline Milking, $\mathrm{h} / \mathrm{d}$ & 0.7 & 2.6 & 4.0 & 4.2 & 4.2 & 4.0 & 3.8 & 3.7 & 3.5 & 3.4 & 2.3 & 0.7 & - \\
\hline Cow-related work, h/d & 4.5 & 5.1 & 5.2 & 5.2 & 5.1 & 5.0 & 4.9 & 4.9 & 4.9 & 4.8 & 4.8 & 4.7 & - \\
\hline Farm-related labor, $\mathrm{h} / \mathrm{d}$ & 1.5 & 1.5 & 1.5 & 1.5 & 1.5 & 1.5 & 1.5 & 1.5 & 1.5 & 1.5 & 1.5 & 1.5 & - \\
\hline Labor, $\mathrm{h} / \mathrm{mo}$ & 178.4 & 221.6 & 283.6 & 279.8 & 289.1 & 269.2 & 271.0 & 269.6 & 252.7 & 258.1 & 219.6 & 185.2 & 2978 \\
\hline
\end{tabular}


Grass supply. Total yearly grass production was assumed to be 13 tonnes DM/ha based on measurements at Moorepark (1982 to 2001) using the method described by Corral and Fenlon (1978). Grass utilization was assumed to be $85 \%$. Grass growth was dependent on nitrogen and the location of the model farm. Grass cover estimates were similar to recommended guidelines (O'Donovan et al., 2002). Nitrogen, phosphorous, and potassium concentrations used in the model were 337,12 , and $33 \mathrm{~kg} / \mathrm{ha}$, respectively. Teagasc nutrient management guidelines were observed; these allowed the recycling of phosphorous and potassium produced on the farm in the form of slurry (Teagasc, 2001).

Land and capital. Land area was treated as an opportunity cost; additional land was rented in when required or leased out when not required for on-farm feeding of animals. Grazing management, silage harvesting, and grass production were similar to that reported previously (Dillon et al., 1995). The land areas for first and second cut silage (ratio 3:2, respectively) and for grazing were optimized to meet silage and grass requirements. Costs for fertilizer application, reseeding, and silage making (contractor, additives, and polythene) were based on the actual area required for silage and grazing.

Land improvements and buildings were depreciated at $10 \% / y r$ using the straight line method, and machinery was depreciated at $20 \%$ using the reducing balance method (O'Mahony, 1992). The book values used at the start of January for buildings and static machinery were those for the 6th and 7th yr as building or purchase, respectively. Provision was made for the purchase and depreciation of new fixed assets during the year. A 15-yr bank term loan was used to fund the cost of land improvements and buildings. The interest rate was fixed at $7.3 \%$, and the loan was considered to be in its 7 th yr; the interest portion of the repayment was considered as an expense.

Labor. Labor requirements were based on the results of a comprehensive farm labor efficiency study on 143 Irish dairy farms (O'Donovan et al., 2003). Total farm labor requirement was divided into 8 main categories (milking, maintenance, grassland, management, calf care, cleaning, veterinary, and miscellaneous). In the model, labor requirement was divided between time associated with the cow and other farm tasks. The labor associated with the cow includes tasks such as actual milking, calf care, cow care, and veterinary. Droving, herding, maintenance, and miscellaneous were included as other tasks. The labor cost was calculated assuming $1848 \mathrm{~h}$ equates to one labor unit/yr at a cost of $€ 22,855$. Full labor costs were included in the MDSM because of its large influence on efficiency and productivity at farm level.
Receipts. The gross milk price was $€ 0.295 / \mathrm{kg}$, based on a reference of $36.0 \mathrm{~g}$ fat $/ \mathrm{kg}$ and $33.0 \mathrm{~g}$ protein $/ \mathrm{kg}$ used by most Irish dairy manufacturers in 2001 . A relative price ratio of 1:2 for fat and protein was assumed based on world market prices and international trends (Veerkamp et al., 2002). Hence, milk payment was based on kilograms of fat (€3.04/kg) plus kilograms of protein (€6.09/kg) delivered minus a cost of $€ 0.017 / \mathrm{kg}$ made up of $€ 0.004$ for levies and $€ 0.013$ for transportation and cooling (Keane et al., 1998). Value-added tax was added to the gross milk price at a rate of $4.3 \%$ in accordance with current tax legislation in Ireland (Teagasc, 2002).

The calf and cull cow prices were based on average prices between 1996 and 1998 (Teagasc, 2002). Cull cow valuation depended on the month of disposal and lactation stage. Prices ranged between $€ 476$ in the 2 nd mo after calving to $€ 373$ at the end of lactation. Male and female calves were sold at 1 mo of age and were valued at $€ 207$ and $€ 336$, respectively.

Costs. The worksheet holds information month-bymonth for each of the operating costs, such as fertilizer application, silage making, veterinary medicine etc. All variable costs (concentrates, fertilizer, reseeding, machinery hire, silage making, veterinary medicine, and AI) were based on current prices (Teagasc, 2002). Reseeding costs were based on 5\% of the farm being reseeded each year with a reseeding cost of $€ 577 /$ ha. Veterinary costs included routine animal treatments as well as compulsory annual tuberculosis and brucellosis testing of animals and drugs involved in correction of infertility problems in cows. Artificial insemination costs were based on 1.7 inseminations per conception with each insemination costing $€ 25.40$ plus a service charge of $€ 11.43$. As for variable costs, all fixed costs (car, electricity, machinery operation and repair, telephone, insurance) were based on current prices (Teagasc, 2002). Two-thirds of the total costs associated with maintenance and operating a car were charged to the farm (O'Sullivan and O'Neill, 2002). Costs associated with operation and servicing the milking parlor were included in the machinery operation and repair costs.

Output indicators. The outputs from the model include financial indicators (operating cash flow, profit and loss account, and balance sheet) and physical outputs such as feed budget, nutrient balance sheet, and physical ratios. Operating cash flows are summarized for each month of the year and indicate the cash surplus or deficit in each month. The estimated farm profit and loss account is presented on a total farm basis as well as per hectare, per cow calving, and per kilogram of milk produced. Farm net profit included total receipts less total costs, including a notional charge for full labor costs. The fixed cost distinguishes interest costs on an 
overdraft account from term liabilities. Interest earned on the cash flow in the current account is distinguished from other farm receipts. The farm balance sheet summarizes the assets and the liabilities of the business, and it estimates net worth.

The physical outputs from the model include physical ratios and a nutrient balance report. Physical outputs also contain a tornado feed-budget graph of the requirements of grass, grass silage, and concentrate for each month of the year on an individual cow basis.

\section{Stochastic Budgeting}

A key and innovative part of the development of MDSM was the inclusion of stochastic simulation modeling. Stochastic features were introduced into the budget. Stochastic simulation was carried out in the MDSM using the computer software @Risk (Palisade, 2000), which works by a process, of "Monte Carlo Sampling." Monte Carlo risk assessment (also called Monte Carlo uncertainty assessment) specifies a probability distribution for each sensitivity parameter, draws a set of those parameters, and repeats the conventional analysis for multiple draws (Phillips and Maldonado, 1999; Phillips, 2000). A sufficiently large number $(10,000)$ of simulations were run with the same input distributions so that the probability distribution functions of the outputs were adequately described (Isukapalli et al., 1998).

Stochastic budgeting was used to model the influence of variation in milk price, concentrate cost, and silage quality, because these 3 factors were considered to have the largest effect on whether S1 was stochastically dominant to the second calving pattern (S2; mean calving date January 27). In S2, a greater proportion of milk was produced from grass silage and concentrate supplementation than from grazed grass; milk price was included, as $77 \%$ of total output came from sale of milk in the model. The values for milk price were obtained from projections from the Food and Agricultural Policy Research Institute-Ireland Outlook 2002 (Binfield et al., 2002). The report projected that milk price would decline by 6 and $9 \%$ in the EU average and Ireland, respectively, by 2010 . The base milk price of $€ 0.281 /$ $\mathrm{kg}$, which corresponded to the year 2000, was reduced by $9 \%$ to correspond to the year 2010 . Variation in milk price over the period from 1995 to 2002, obtained from Central Statistics Office (CSO) (2003), was used to determine the spread. A computer program called Bestfit (Palisade, 2000) was used to estimate a distribution of milk price from the CSO data. The same approach was used to estimate a distribution of concentrate costs. The Bestfit program used the Chi square test to rank 1 to 38 distributions that best suited the data. The program picked the Beta General Distribution as the one that best suited the data. For silage quality, the stochastic variables were included as triangular distributions, where the minimum, most likely, and maximum values were included (Hardaker et al., 1997). The most likely, minimum, and maximum values were 680,620 , and 740 $\mathrm{g} / \mathrm{kg}$ DM digestibility, respectively; these were based on results of analysis of silage samples submitted to Teagasc, Grange Laboratories over the period 1993 to 1996 (Keating and O'Kiely, 1997). The stochastic variables were simulated simultaneously, and it was assumed that there was no correlation between variables. Binfield et al. (2002) projected that in Ireland milk price would reduce by $30 \%$ between 2002 and 2010; at the same time, concentrate costs would remain unchanged. Similarly data from the CSO in Ireland over the period from 1995 to 2002 indicated no significant correlation between milk price and concentrate cost, with $<20 \%$ of the variation accounted for. It was assumed that silage quality was independent of concentrate cost and milk price.

\section{Milk Production Scenarios}

The milk quota system, introduced by the EU in 1984, currently limits the level of herd milk production in Ireland. Milk production on farms is restricted to available milk quota on the holding. This quota is on milk yield adjusted for fat content using the following formula:

Adjusted quota $=$

[quota $(1+0.18(\mathrm{BF} \%$ reference year - current $\mathrm{BF} \%)$ ]

where $\mathrm{BF} \%$ is butter fat percentage of the milk and the reference year was 1984. It was assumed that farmers were constrained by the EU milk quota, and the consequence of higher milk yield per cow would be a reduction in cow numbers (i.e., evaluation was based on a fixed output). This is representative of the present quota position.

Two milk production scenarios were investigated that corresponded to two different calving patterns. In S1 (default scenario), 70, 20, and 10\% of the cows in the herd calved in the months of February, March, and April, respectively; this corresponded to a mean calving date of February 24. In the S2 scenario, 70, 20, and $10 \%$ of the cows in the herd calved in the months of January, February, and March, respectively; this corresponded to a mean calving date of January 27 and a calving spread of $89 \mathrm{~d}$. The physical and financial outputs from the 2 calving patterns are presented.

\section{Model Validation}

Model validation is a test of the ability of the model to accurately assess the intended application (Milham, 
1998; Sørensen, 1990). In the present study, actual data from 21 spring calving dairy herds and simulated data for the S1 scenario were compared for the year 2001 to determine the reliability of key model outputs. The actual data were obtained from herds that were part of a Dairy Management Information System (DairyMIS) (Crosse, 1986) attached to Moorepark. The DairyMIS is a recorder-based computer system for collecting detailed farm inputs and production information on a monthly basis. Financial and physical data for these farms for the past $20 \mathrm{yr}$ were available; however, only 2001 data were used as the costs in the model were based on 2001-2002 prices. Replacement heifer rearing was considered to be part of the dairy enterprise. In farms where there was some beef production (3 farms in total), all production costs on the farm were reduced on a livestock-equivalent basis (O'Sullivan and O'Neill, 2002). The model output data were compared with the mean, minimum, and maximum of the comparable variables from the selected farms.

\section{RESULTS}

\section{Bio-economic Model}

Table 1 shows the number of animals present, animal sales and purchases, milk production and composition, feed requirement, land use, and labor requirement for each of the 12 mo of the year for S1 scenario. Cow numbers averaged 73.0 over the year, and 15.7 replacement heifers were required to replace the 1.2 cow deaths and 14.5 cows culled. The corresponding values for S2 were 71.5 cows, 15.4 replacement heifers, 1.2 cow deaths, and 14.2 cows culled. Number of male and female calves sold were 38.4 and 21.1 for $\mathrm{S} 1$ and 37.6 and 20.7 for S2, respectively. The farm produced a total of 462,621 and $462,308 \mathrm{~kg}$ of milk in the $\mathrm{S} 1$ and $\mathrm{S} 2$ scenarios, respectively, and 14,584 and $14,295 \mathrm{~kg}$ of this were fed to calves. Peak milk production was in May and lowest milk production was in January in S1; the corresponding months were April and December in S2. Total labor requirement for the year in S1 was 2978 hs (1.61 labor units); in S2, total labor was $2922 \mathrm{~h}$ (1.58 labor units).

Figure 2 shows the average feed intake per cow for each month of the year for the S1 scenario. The average stocking rate over the total year was $2.35 \mathrm{cows} / \mathrm{ha}$. Total DMI (kg per cow) were 3590, 1201, and 350 of grazed grass, grass silage, and concentrate, respectively, and these correspond to 70,23 , and $7 \%$ of the total diet, respectively.

Grass cover ranged from a peak of $1074 \mathrm{~kg} \mathrm{DM} / \mathrm{ha}$ in September to a low of $434 \mathrm{~kg} \mathrm{DM} / \mathrm{ha}$ in November; the opening farm cover was $700 \mathrm{~kg} \mathrm{DM} / \mathrm{ha}$. Figure 3 shows the average feed intake per cow for each month

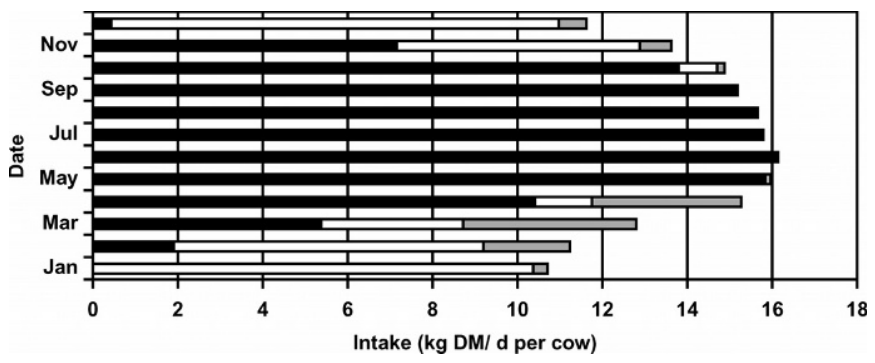

Figure 2. Feed intake composition for each month of the year for a mean calving date of February 24. Grazed grass (solid), grass silage (open), concentrate (cross-hatched).

of the year for the $\mathrm{S} 2$ scenario. In $\mathrm{S} 2$, the average stocking rate over the total year was 2.44 cows/ha. Total DMI (kg per cow) were 3409, 1183, and 709 of grazed grass, grass silage, and concentrate, respectively, and these correspond to 64,22 , and $13 \%$ of the total diet, respectively.

\section{Financial Performance}

Table 2 shows the profit and loss account for the MDSM for S1 using the assumptions already outlined. In $\mathrm{S} 1$, total farm receipts and farm net profit were $€ 177,987$ and $€ 53,547$, respectively. These correspond to $€ 0.385$, €0.114, $€ 0.122$, and $€ 0.116 / \mathrm{kg}$, for receipts, variable costs, fixed costs, and farm net profit, respectively. Milk accounted for $77 \%$ of total sales in S1; variable, fixed, and depreciation costs accounted for 42,45 , and $13 \%$ of total costs, respectively.

Table 3 shows the profit and loss account for the MDSM for S2. Total farm receipts and farm net profit were $€ 177,152$ and $€ 51,687$, respectively. These correspond to $38.3,12.0,12.0$, and 11.2 cents (euro)/kg for receipts, variable costs, fixed costs, and farm net profit, respectively. As in S1, milk accounted for $77 \%$ of total sales in $\mathrm{S} 2$; variable, fixed, and depreciation costs accounted for and 44,44 , and $12 \%$ of total costs, respec-

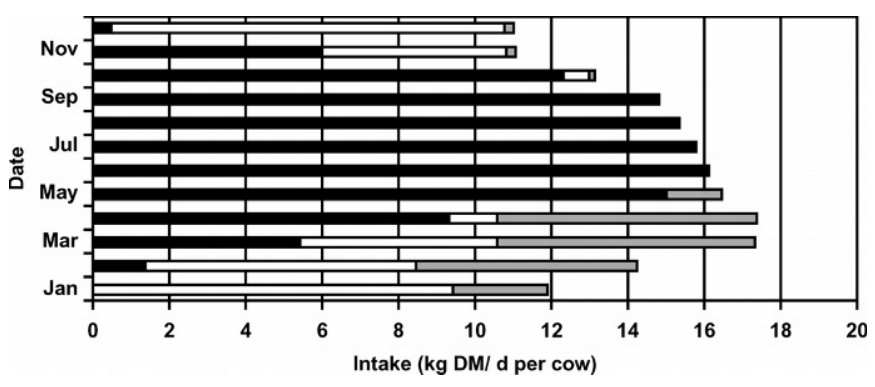

Figure 3. Feed intake composition for each month of the year for a mean calving date of January 27. Grazed grass (solid), grass silage (open), and concentrate (cross-hatched). 
Table 2. Trading profit and loss account for the Moorepark Dairy Systems Model for the S1 scenario (default scenario; mean calving date February 24).

\begin{tabular}{|c|c|c|c|c|c|}
\hline & $\begin{array}{l}\text { Subtotal } \\
\left(€^{1}\right)\end{array}$ & $\begin{array}{l}\text { Total } \\
(€)\end{array}$ & $€ /$ ha & $\begin{array}{l}€ \text { per } \\
\text { cow } \\
\text { calving }\end{array}$ & $\begin{array}{l}\mathrm{c}^{2} / \mathrm{kg} \text { milk } \\
\text { produced }\end{array}$ \\
\hline \multicolumn{6}{|l|}{ Receipts } \\
\hline Milk & 136,181 & & 3596 & 1717 & 29.4 \\
\hline Livestock & 41,806 & & 1104 & 527 & 9.0 \\
\hline Total receipts & & 177,987 & 4699 & 2245 & 38.5 \\
\hline \multicolumn{6}{|l|}{ Variable costs } \\
\hline Concentrates & 7187 & & 190 & 91 & 1.6 \\
\hline Fertilizer, lime, and reseeding & 11,029 & & 291 & 139 & 2.4 \\
\hline Land rental & -1000 & & -26 & -13 & -0.2 \\
\hline Livestock purchases & 21,947 & & 579 & 277 & 4.7 \\
\hline Machinery hire & 809 & & 21 & 10 & 0.2 \\
\hline Milk replacer & - & & - & - & - \\
\hline Silage making & 6450 & & 170 & 81 & 1.4 \\
\hline Veterinary (AI and medicine) & 6364 & & 168 & 80 & 1.4 \\
\hline Quota lease & - & & - & - & - \\
\hline Total variable costs & & 52,786 & 1394 & 666 & 11.4 \\
\hline \multicolumn{6}{|l|}{ Fixed costs } \\
\hline Car use & 3167 & & 84 & 40 & 0.7 \\
\hline Electricity & 1120 & & 30 & 14 & 0.2 \\
\hline Labor & 36,830 & & 972 & 464 & 8.0 \\
\hline Machinery operation and repair & 3395 & & 90 & 43 & 0.7 \\
\hline Phone & 457 & & 12 & 6 & 0.1 \\
\hline Insurance, transportation, other & 3369 & & 89 & 42 & 0.7 \\
\hline Interest repayments-term loan & 8202 & & 217 & 103 & 1.8 \\
\hline Total fixed costs & & 56,539 & 1493 & 713 & 12.2 \\
\hline \multicolumn{6}{|l|}{ Depreciation charges } \\
\hline Land improvements & 1443 & & 38 & 18 & 0.3 \\
\hline Buildings & 9927 & & 262 & 125 & 2.2 \\
\hline Machinery & 4049 & & 107 & 51 & 0.9 \\
\hline New fixed assets & - & & - & - & - \\
\hline Total depreciation charges & & 15,419 & 407 & 194 & 3.3 \\
\hline Total farm costs & & 124,744 & 3294 & 1573 & 27.0 \\
\hline Interest earned & 304 & & 8 & 4 & 0.1 \\
\hline Sale fixed assets (profit-loss) & - & & - & - & - \\
\hline Farm net profit (before tax) & & 53,547 & 1414 & 675 & 11.6 \\
\hline
\end{tabular}

${ }^{1} € 1=\$ 1.15$ (US) as of September 2003.

${ }^{\mathrm{c}} \mathrm{c}=$ Cents (euro).

tively. Labor costs accounted for $65 \%$ of total fixed costs in both $\mathrm{S} 1$ and $\mathrm{S} 2$.

\section{Stochastic Budgeting}

Figure 4 shows a cumulative density function (CDF) of the influence of variation in milk price, concentrate costs, and silage quality on the spread of farm profit in both S1 and S2. The cumulative probability distribution shows that $\mathrm{S} 1$ is stochastically dominant over S2. Firstdegree stochastic dominance means that the CDF further to the right are preferred. For any given level of risk, there is a higher level of profit, or, conversely, for a given level of profit, there is lower risk when the $\mathrm{CDF}$ is further to the right. The mean farm profit was $€ 33,309$ and $€ 30,895$ for $\mathrm{S} 1$ and S2, respectively. The range in farm profit with a $90 \%$ confidence interval (5 to $95 \%$ ) was $€ 26,865$ to $€ 38,924$ in $\mathrm{S} 1$; the corresponding values in S2 were $€ 24,123$ to $€ 36,905$.
The simulation data were further analyzed using multiple regression to quantify the relative contributions of each stochastic input variable to the variation in the output variable. Estimated profit was regressed on milk price, concentrate price, and silage quality. The partial coefficients of determination were calculated as $99.2,0.7$, and $0.1 \%$ for milk price, concentrate cost, and silage quality, respectively, in $\mathrm{S} 1$; the corresponding values in S2 were $97.6,2.3$, and $0.1 \%$.

\section{Model Validation}

Table 4 shows the physical performance on the 21 DairyMIS farms and that modeled in the MDSM using the $\mathrm{S} 1$ scenario. The results indicate that the MDSM provided a reliable representation of the observed and average performance in the DairyMIS farms. On average, the culling rates, milk price, milk composition, proportion of farm harvested for first and second cut 
Table 3. Trading profit and loss account for the Moorepark Dairy Systems Model for the S2 scenario (mean calving date January 27).

\begin{tabular}{|c|c|c|c|c|c|}
\hline & $\begin{array}{l}\text { Subtotal } \\
\left(€^{1}\right)\end{array}$ & $\begin{array}{l}\text { Total } \\
(€)\end{array}$ & $€ /$ ha & $\begin{array}{l}€ \text { per } \\
\text { cow } \\
\text { calving }\end{array}$ & $\begin{array}{l}\mathrm{c}^{2} / \mathrm{kg} \text { milk } \\
\text { produced }\end{array}$ \\
\hline \multicolumn{6}{|l|}{ Receipts } \\
\hline Milk & 136,175 & & 3839 & 1752 & 29.5 \\
\hline Livestock & 40,977 & & 1155 & 527 & 8.9 \\
\hline Total receipts & & 177,152 & 4994 & 2279 & 38.3 \\
\hline \multicolumn{6}{|l|}{ Variable costs } \\
\hline Concentrates & 12,580 & & 355 & 162 & 2.7 \\
\hline Fertilizer, lime, and reseeding & 10,320 & & 291 & 133 & 2.2 \\
\hline Land rental & -2130 & & -60 & -27 & -0.5 \\
\hline Livestock purchases & 21,512 & & 606 & 277 & 4.7 \\
\hline Machinery hire & 793 & & 22 & 10 & 0.2 \\
\hline Milk replacer & - & & - & - & - \\
\hline Silage making & 6270 & & 177 & 81 & 1.4 \\
\hline Veterinary (AI and medicine) & 6241 & & 176 & 80 & 1.4 \\
\hline Quota lease & - & & - & - & - \\
\hline Total variable costs & & 55,586 & 1564 & 715 & 12.0 \\
\hline \multicolumn{6}{|l|}{ Fixed costs } \\
\hline Car use & 3167 & & 89 & 41 & 0.7 \\
\hline Electricity & 1119 & & 32 & 14 & 0.2 \\
\hline Labor & 36,133 & & 1019 & 465 & 7.8 \\
\hline Machinery operation and repair & 3381 & & 95 & 43 & 0.7 \\
\hline Phone & 457 & & 13 & 6 & 0.1 \\
\hline Insurance, transportation, other & 3302 & & 93 & 42 & 0.7 \\
\hline Interest repayments-term loan & 7834 & & 221 & 101 & 1.7 \\
\hline Total fixed costs & & 55,393 & 1562 & 713 & 12.0 \\
\hline \multicolumn{6}{|l|}{ Depreciation charges } \\
\hline Land improvements & 1443 & & 41 & 19 & 0.3 \\
\hline Buildings & 9426 & & 266 & 121 & 2.0 \\
\hline Machinery & 4049 & & 114 & 52 & 0.9 \\
\hline New fixed assets & - & & - & - & - \\
\hline Total depreciation charges & & 14,918 & 421 & 192 & 3.2 \\
\hline Total farm costs & & 125,897 & 3549 & 1620 & 27.2 \\
\hline Interest earned & 433 & & 12 & 6 & 0.1 \\
\hline Sale fixed assets (profit-loss) & - & 433 & & & \\
\hline Farm net profit (before tax) & & 51,687 & 1457 & 665 & 11.2 \\
\hline
\end{tabular}

${ }^{1} € 1=\$ 1.15$ (US) as of September 2003.

${ }^{\mathrm{c}} \mathrm{c}=$ cents (euro).

silage, phosphorus, and potash application rates were very similar in the DairyMIS farms to those obtained in the MDSM. There were modest differences between data obtained in the MDSM and the average data for

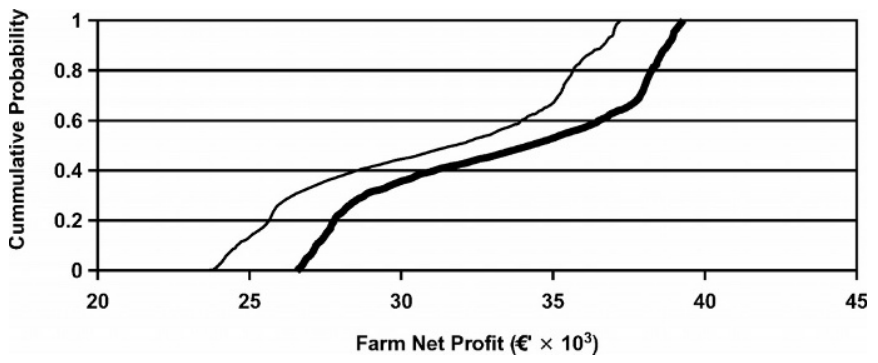

Figure 4. Cumulative probability distribution showing the influence of milk price, concentrate costs, and silage quality on farm net profit for a mean calving date of February 24 (thick line) and a mean calving date of January 27 (thin line). $€=\$ 1.15$ (US) as of September 2003. the 21 DairyMIS farms for calf mortality (MDSM was 6.1 percentage points lower), milk production per cow (MDSM was $251 \mathrm{~kg}$ per cow higher), stocking rate (MDSM was 0.12 cows/ha lower), nitrogen application rates (MDSM was $48 \mathrm{~kg} \mathrm{~N} /$ ha higher), and concentrate fed per cow (MDSM was $209 \mathrm{~kg}$ lower). Average cull cow and calf prices were $€ 36$ and $€ 106$ lower and higher, respectively, in the DairyMIS farms than in the MDSM. However, all of these parameters modeled in the MDSM were within the range obtained in the 21 DairyMIS farms.

Tables 5 and 6 show a comparison of the variable and fixed costs for the DairyMIS farms (mean, maximum, and minimum and standard deviation) and in the MDSM on a per kilograms of milk basis and a per cow basis, respectively. All of the financial parameters per kilogram of milk and per cow in the MDSM were within the range obtained on the DairyMIS farms. Total receipts, variable costs, fixed costs, and net profit per 
Table 4. Physical performance on the Moorepark Dairy Systems Model (MDSM) and on 21 dairy farms.

\begin{tabular}{|c|c|c|c|c|c|}
\hline & \multirow[b]{2}{*}{ MDSM } & \multicolumn{4}{|c|}{ DairyMIS $^{1}$} \\
\hline & & Average & $\pm \mathrm{SD}$ & Minimum & Maximum \\
\hline Culling, \% & 20 & 19 & 10.4 & 4 & 51 \\
\hline Calf mortality, $\%$ & 4.0 & 10.1 & 5.45 & 4.4 & 21.6 \\
\hline Milk produced, kg per cow & 5834 & 5583 & 480.6 & 4909 & 6595 \\
\hline Milk produced, $\mathrm{kg} / \mathrm{ha}$ & 12,213 & 10,615 & 1619.1 & 8599 & 15,209 \\
\hline Milk sold, $\mathrm{kg}$ per cow & 5650 & 5374 & 421.6 & 4831 & 6189 \\
\hline Milk fed to calves, $\mathrm{kg}$ & 190 & 207 & 129.3 & - & 445 \\
\hline Milk price, $\mathrm{c}^{2} / \mathrm{kg}$ & 30.4 & 31.4 & 1.57 & 25.7 & 33.4 \\
\hline Fat concentration, $\%$ & 3.84 & 3.87 & 0.08 & 3.68 & 3.98 \\
\hline Protein concentration, $\%$ & 3.40 & 3.40 & 0.07 & 3.31 & 3.49 \\
\hline Stocking rate, ${ }^{3}$ LU/ha & 2.35 & 2.47 & 0.26 & 1.99 & 2.88 \\
\hline Proportion of farm 1st cut & 0.40 & 0.43 & 0.94 & 0.30 & 0.59 \\
\hline Proportion of farm 2 nd cut & 0.27 & 0.27 & 0.09 & 0.08 & 0.37 \\
\hline Fertilizer nitrogen, kg/ha & 337 & 289 & 66.5 & 182 & 456 \\
\hline Fertilizer phosphorus, $\mathrm{kg} / \mathrm{ha}$ & 12.4 & 13.2 & 10.46 & 1.0 & 39.0 \\
\hline Fertilizer potassium, kg/ha & 33.4 & 33.5 & 26.02 & 1.0 & 98.0 \\
\hline Concentrate, $\mathrm{kg}$ per cow & 388 & 597 & 215.8 & 310 & 1180 \\
\hline Concentrate costs, $€^{4}$ per cow & 74 & 94 & 37.3 & 47 & 171 \\
\hline Cull cow price, $€$ per cow & 413 & 449 & 103.5 & 256 & 695 \\
\hline Calf price, $€$ per cow & 278 & 172 & 66.6 & 76 & 332 \\
\hline
\end{tabular}

cow were $€ 78$ greater, $€ 199$ lower, $€ 161$ greater, and $€ 2$ lower, respectively, in the MDSM than the average for the DairyMIS farms. Total receipts, variable costs, fixed costs, and net profit (euro cents/kg milk) were 2.1 greater, 3.8 lower, 3.0 greater, and 0.5 greater, respectively, in the MDSM than the average for the DairyMIS farms.

\section{DISCUSSION}

\section{Bio-economic Model}

The system of milk production that has developed in Ireland is a 'hybrid' using grazed pasture, pasture silage, and concentrates on an annual basis. This is primarily due to the seasonal nature of grass production and some climatic constraints. Concentrating calving in the months of February and March allows maximum use of grazed grass during lactation (Dillon et al., 1995). Some $66 \%$ of all Irish dairy cows calve in February, March, and April (Irish Cattle Breeding Statistics, 2001). In the MDSM (S1), the stocking rate of 2.35 cows/ ha and $70 \%$ of the total diet being contributed as grazed grass are both lower than those being achieved in New Zealand. In New Zealand, McCall and Clark (1999) obtained a stocking rate of 2.85 cows/ha with $98 \%$ of the total diet being contributed from grazed grass. Milk production was 12,213 and $15,856 \mathrm{~kg} / \mathrm{h}$ a for the MDSM and the New Zealand systems, respectively. The greater proportion of the milk production being produced from grazed grass in S1 compared with S2 is similar to that reported previously (Dillon et al., 1995).

\section{Financial Performance}

The good financial performance in the MDSM for S1 relative to 1999,2000 , and 2002 is due mainly to higher milk price in 2001. Fingleton (2002) using National Farm Survey data showed that net margins per liter of milk produced on specialist dairy farms were $1 \phi$ higher in 2001 than the average of 1999, 2000, and 2002. The net profit per cow achieved in the MDSM (€675) is similar to that reported by Fingleton (2002) from the National Farm Survey of Irish specialist dairy farms (€678). Comparisons of total milk production costs between Ireland and other EU countries have shown that Ireland maintains a consistent competitive advantage over all other EU countries with the exception of Belgium (Boyle et al., 1992). However, costs of milk production in Ireland are 2.5 and 1.6 times those in New Zealand and Australia, respectively (Anonymous, 1993). The better financial performance of $\mathrm{S} 1$ relative to $\mathrm{S} 2$ is similar to that reported previously (Crosse and Dillon, 1993) and is a result of the lower cost of milk production because more of the cow's diet is made up of grazed grass, which is a cheaper feed than either grass silage or purchased concentrate.

\section{Stochastic Budgeting}

Sensitivity analysis, although a valid and useful technique for determining the range of feasible outcomes 
Table 5. Financial performance $\left(c^{1} / \mathrm{kg}\right)$ in the Moorepark Dairy Systems Model (MDSM) and on 21 dairy farms.

\begin{tabular}{|c|c|c|c|c|c|}
\hline & \multirow[b]{2}{*}{ MDSM } & \multicolumn{4}{|c|}{ DairyMIS $^{2}$} \\
\hline & & Mean & $\pm \mathrm{SD}$ & Minimum & Maximum \\
\hline \multicolumn{6}{|l|}{ Receipts (c/kg) of milk } \\
\hline Milk & 30.4 & 30.5 & 1.23 & 27.4 & 32.6 \\
\hline Livestock & 9.3 & 7.7 & 2.96 & 3.0 & 17.4 \\
\hline Total receipts & 39.7 & 37.6 & 3.06 & 31.4 & 46.7 \\
\hline \multicolumn{6}{|l|}{ Variable costs } \\
\hline Concentrates & 1.6 & 1.8 & 0.75 & 1.0 & 3.3 \\
\hline Fertilizer lime reseeding & 2.5 & 2.2 & 0.55 & 1.5 & 3.6 \\
\hline Land and quota rental & -0.2 & 3.2 & 2.66 & - & 9.3 \\
\hline Livestock purchases & 4.9 & 4.7 & 2.42 & 0.6 & 11.9 \\
\hline Silage making & 1.4 & 1.6 & 0.71 & 0.1 & 3.2 \\
\hline Veterinary (AI and medicine) & 1.4 & 1.7 & 0.50 & 0.9 & 3.0 \\
\hline Total variable costs & 11.8 & 15.6 & 4.66 & 7.9 & 23.3 \\
\hline \multicolumn{6}{|l|}{ Fixed costs } \\
\hline Car and phone use & 0.8 & 0.4 & 0.18 & 0.1 & 0.9 \\
\hline Electricity & 0.3 & 0.5 & 0.12 & 0.2 & 0.7 \\
\hline Labor, living expenses & 8.2 & 6.6 & 1.06 & 4.6 & 10.3 \\
\hline Machinery operation & 0.8 & 1.1 & 0.46 & 0.6 & 2.5 \\
\hline Insurance, transportation, other & 0.8 & 0.5 & 0.20 & 0.3 & 0.9 \\
\hline Farm maintenance & - & 0.4 & 0.36 & 0.1 & 1.6 \\
\hline Interest repayment-term loan & 1.8 & - & - & - & - \\
\hline Miscellaneous & - & 0.3 & 0.23 & - & 0.8 \\
\hline Total fixed costs & 12.6 & 9.6 & 1.55 & 8.1 & 14.7 \\
\hline \multicolumn{6}{|l|}{ Depreciation charges } \\
\hline Land improvements & 0.3 & - & - & - & - \\
\hline Buildings & 2.2 & 0.7 & 0.61 & - & 2.1 \\
\hline Machinery & 0.9 & 0.6 & 0.56 & - & 2.1 \\
\hline New fixed assets & - & - & - & - & - \\
\hline Total depreciation changes & 3.4 & 1.3 & 1.13 & - & 3.8 \\
\hline Total farm costs & 27.8 & 26.1 & 6.74 & 18.6 & 37.2 \\
\hline Interest earned & 0.1 & - & - & - & - \\
\hline Net profit & 12.0 & 11.5 & 4.64 & 0.5 & 17.7 \\
\hline
\end{tabular}

from a model, does not give any indication of the likelihood of particular results being achieved (Milham and Hardaker, 1990). Risk assessment is a process for identifying adverse consequences and their associated probabilities (McKone, 1996). Whole farm stochastic budgeting involves developing a model that mimics the operation of a business and provides projections of financial performance while taking account of the uncertainty inherent in many aspects of the decisions (Milham, 1998). Beneficial Monte Carlo simulations can only be achieved when meaningful estimates of the input stochastic variables are used in the model. Hard aker et al. (1997) stated that the selected variables to be added stochastically are usually those that will have the largest effect on the level of risk of a certain outcome. The results from a Monte Carlo simulation are only as valid as the input parameter data and the assumptions used in the analysis (Petersen, 2000). There are many sources of data and a variety of methods that can be used to determine the input distributions using Monte Carlo analysis procedures (Petersen and Barraj, 1996). Lien and Hardaker (2001) noted that, in the case where historical data are not relevant, the values may be obtained from expert opinion. In the present study, the factors that were considered to have an effect on farm profit were milk price, concentrate costs, and silage quality.

A powerful risk efficiency criterion is stochastic dominance. The stochastically efficient, or dominant, set is found by comparing the CDF of risky prospects (Thomas et al., 1997). A CDF contains all of the information on the output distribution of the risky prospects and, therefore, provides a useful decision-making criterion by assessing stochastic dominance. When the $\mathrm{S} 1$ and $\mathrm{S} 2$ were presented on the CDF, the $\mathrm{S} 1$ scenario was further to the right than S2. Thus, S1 was stochastically dominant over S2 and would be preferred.

In the sensitivity analysis, the partial coefficients of determination calculated for each input variable measure the percentage variation in the output variable explained by that particular input distribution (Palisade, 2000). Milk price had, by far, the largest effect on the overall output distribution, which means that farm profit is very sensitive to any changes in milk 
Table 6. Financial performance per cow in the Moorepark Dairy Systems Model (MDSM) and on 21 dairy farms.

\begin{tabular}{|c|c|c|c|c|c|}
\hline & \multirow[b]{2}{*}{ MDSM } & \multicolumn{4}{|c|}{ DairyMIS $^{1}$} \\
\hline & & Mean & $\pm \mathrm{SD}$ & Minimum & Maximum \\
\hline \multicolumn{6}{|l|}{ Receipts $\left(€^{2}\right)$} \\
\hline Milk & 1717 & 1726 & 190.3 & 1440 & 2243 \\
\hline Livestock & 527 & 442 & 168.4 & 264 & 1026 \\
\hline Total receipts & 2245 & 2167 & 243.8 & 1813 & 2760 \\
\hline \multicolumn{6}{|l|}{ Variable costs } \\
\hline Concentrates & 91 & 108 & 40.5 & 59 & 201 \\
\hline Fertilizer lime reseeding & 139 & 128 & 35.1 & 83 & 220 \\
\hline Quota lease and land rental & -13 & 176 & 145.2 & - & 566 \\
\hline Livestock purchases & 277 & 266 & 137.9 & 49 & 705 \\
\hline Silage making & 81 & 92 & 42.5 & 3 & 186 \\
\hline Veterinary (AI and medicine) & 80 & 96 & 30.8 & 52 & 179 \\
\hline Total variable costs & 666 & 865 & 232.6 & 473 & 1339 \\
\hline \multicolumn{6}{|l|}{ Fixed costs } \\
\hline Car and phone use & 46 & 24 & 10.6 & 5 & 46 \\
\hline Electricity & 14 & 25 & 7.9 & 12 & 47 \\
\hline Labor, living expenses & 464 & 375 & 31.6 & 369 & 513 \\
\hline Machinery operation & 43 & 62 & 29.7 & 30 & 147 \\
\hline Insurance, transportation, other & 42 & 27 & 11.9 & 14 & 47 \\
\hline Farm maintenance & - & 20 & 21.5 & 4 & 75 \\
\hline Interest repayment-term loan & 103 & - & - & - & - \\
\hline Miscellaneous & - & 17 & 12.6 & - & 40 \\
\hline Total fixed costs & 713 & 552 & 74.6 & 473 & 736 \\
\hline \multicolumn{6}{|l|}{ Depreciation charges } \\
\hline Land improvements & 18 & - & - & - & - \\
\hline Buildings & 125 & 38 & 35.5 & - & 123 \\
\hline Machinery & 51 & 35 & 31.3 & - & 114 \\
\hline New fixed assets & - & - & - & - & - \\
\hline Total depreciation changes & 194 & 73 & 64.4 & - & 205 \\
\hline Total farm costs & 1573 & 1490 & 275.9 & 1106 & 2136 \\
\hline Interest earned & 4 & - & - & - & - \\
\hline Net profit & 675 & 677 & 300.5 & 24 & 1132 \\
\hline
\end{tabular}

${ }^{1}$ DairyMIS =Dairy Management Information System.

${ }^{2} € 1=\$ 1.15$ (US) as of September 2003 .

price. Silage quality had similar influences in both $\mathrm{S} 1$ and S2, as similar amounts of silage were used in both scenarios. Concentrate cost had a much larger influence in S2 than in $\mathrm{S} 1$ because much larger amounts of concentrate were used in $\mathrm{S} 2$.

\section{Model Validation}

Model validation is dependent upon quantitative and qualitative analyses of differences between simulated and actual data. An essential requirement when building a model is that the model adequately represents the system (Damborg, 1985). The validation determines the extent to which simulated results match actual data and, therefore, test the assumptions inherent in the model structure and function. In the present study, there was good agreement between the actual farm data and the simulated results. Also, the net profit of $€ 677$ per cow obtained in the DairyMIS farms is similar to the $€ 678$ per cow in specialist Irish dairy herds (Fingleton, 2002). There were differences in land rental and interest repayment on term loans. It was assumed that there was no milk quota leasing in the simulated model, but there was milk quota leasing in the group of farms. It was not possible to obtain the level of borrowing on the DairyMIS farms. However, the model had interest charges and no lease charges while the farms had lease charges and no interest charges; both costs were similar and therefore, cancelled each other.

\section{CONCLUSIONS}

The MDSM is a stochastic budgetary simulation model of a dairy farm. It was used to simulate the many biological (milk yield and composition, live weight, nutritional requirement, fertilizer), physical (land, labor, buildings), and economic (costs, valuations, profit and loss account, balance sheet) processes on a typical Irish dairy farm. Stochastic budgeting, using Monte Carlo simulation, was used to model the influence of variation in key input and output variables on farm profit. Validations of the model showed that it can be used with confidence to study systems of milk production in Ireland. Therefore, it can be concluded that the model 
developed can be used to examine different questions relating to institutional and technical change on Irish dairy farms. An earlier version of this model was used to derive economic values for milk, fat and protein yield, calving interval, and cow longevity for pasture-based systems in Ireland (Veerkamp et al., 2002). It is anticipated that the MDSM will be used to investigate the influence of dairy cow genotype (Kennedy et al., 2002) and breed (Dillon et al., 2003) on farm profit. It is also anticipated that the MDSM will be used to investigate the influence of change in future milk pricing policies on farm profitability.

\section{ACKNOWLEDGMENTS}

The authors acknowledge John Walsh and Seamus Crosse, who had been involved in the initial development of the MDSM. Their contribution to the development of the model is greatly appreciated.

\section{REFERENCES}

Anonymous. 1993. International benchmarking in the Australian dairy industry. Prepared for the Dairy Research and Development Corporation by the Boston Consulting Group, incorporating Pappas, Carter, Evans, and Koop.

Baldwin, R. L., J. France, D. E. Beever, M. Gill, and J. H. M. Thornley. 1987. Metabolism of the lactating cow. III. Properties of mechanistic models suitable for evaluation of energetic relationship and factors involved in partition of nutrients. J. Dairy Res. 54:133145.

Berentsen, P. B. M., and G. W. J. Giesen. 1995. An environmentaleconomic model at farm level to analyse institutional and technical change in dairy farming. Agric. Syst. 49:153-175.

Binfield, J., T. Donnellan, K. Hanrahan, K. McQuinn, and P. West hoff. 2002. The baseline outlook for the agriculture sector in the EU and Ireland. Pages 13-47 in FABRI Ireland Outlook 2002. Medium Term Analysis for the Agri-Food Sector. Teagasc, Rural Economy Research Centre, Dublin, Ireland.

Blackburn, H. D., and T. C. Cartwright. 1987. Description and validation of the Texas A and M sheep simulation model. J. Anim. Sci. 65:373-386.

Bowman, P. J. 1989. Farm management strategies for improving the quality of fine wool. Ph.D. Diss., University of Canterbury, New Zealand.

Boyle, G. E., B. Kearney, D. McCarthy, and M. Keane. 1992. The competitiveness of Irish agriculture. Allied Ir. Banks Ir. Farmers J.

Buckley, F., P. Dillon, S. Crosse, F. Flynn, and M. Rath. 2000. The performance of Holstein-Friesian dairy cows of high and medium merit for milk production on grass based feeding systems. Livest. Prod. Sci. 64:107-119.

Bywater, A. C., and O. J. Cacho. 1994. Use of simulation models in research. Proc. NZ Soc. Anim. Prod. 54:403-412.

Central Statistics Office. 2003. Principal Statistics in Relation to Agriculture. Central Statistics Office, Cork, Ireland.

Corral, A. J., and J. S. Fenlon. 1978. A comparative method for describing the seasonal distribution of production from grasses. J. Agric. Sci. 91:61-67.

Crosse, S. 1986. The development and implementation of a computerised management information system for Irish Dairy Farmers. Ph.D. Diss., National Univ. of Ireland, Dublin.

Crosse, S., and P. Dillon. 1993. Milk production systems-Management and economic considerations. Ir. Grassl. Anim. Prod. Assoc. J. 27:3-8.
Damborg, M. 1985. An example of error analysis in dynamic model validation. Simulation 44:301.

Dillon P., F. Buckley, P. O'Connor, D. Hegarty, and M. Rath. 2003. A comparsion of different dairy cow breeds on a seasonal grassbased system of mil production. 1. Milk production, live weight, body condition score and DM intake. Livest. Prod. Sci. 83:21-33.

Dillon, P., S. Crosse, G. Stakelum, and F. Flynn. 1995. The effect of calving date and stocking rate on the performance of springcalving dairy cows. Grass Forage Sci. 50:286-299.

Fingleton, W. 2002. The situation and outlook for dairying 2002/2003. In Proc. Situation and Outlook in Ir. Agric. 2002/03, Teagasc, Dublin, Ireland.

Hardaker, J. B., R. B. M Huirne, and J. R. Anderson. 1997. Pages 30-84 in Coping with Risk in Agriculture. CAB Int., London, UK.

Irish Cattle Breeding Statistics. 2001. (ICBF) Irish Cattle Breeding Statistics. Irish Cattle Breeding Federation, Shinagh House, Bandon, Co. Cork, Ireland.

Isukapalli, S. S., A. Roy, and P. G. Georgopoulos. 1998. Stochastic response surface methods (SRSMs) for uncertainty propagation: Application to environmental and biological systems. Risk Anal. 18(3):351-363.

Jalvingh, A. W., A. A. Dijkhuizen, and J. A. M. Van Arendonk. 1992. Dynamic probabilistic modeling of reproduction and replacement management in sow herds. General aspects and model description. Agric. Syst. 39:133-152.

Jarrige, R. (Ed.). 1989. Ruminant Nutrition, Recommended Allowances and Feed Tables. John Libbey Eurotext, Montrougue, France.

Keane, M., P. Enright, and E. Shanahan. 1998. Management techniques and milk transcript. In 25th Int. Dairy Cong., Aarhus, Denmark.

Keating, T., and P. O'Kiely. 1997. Irish farm silage 1993-1996. Pages 123-124 in Proc. Agric. Res. Forum, Faculty of Agriculture, U.C.D. Belfield, Dublin. Teagasc, Ireland.

Kennedy, J., P. Dillon, P. Faverdin, L. Delaby, F. Buckley, and M. Rath. 2002. The influence of cow genetic merit for milk production on response to level of concentrate supplementation in a grass based system. J. Anim. Sci. 75:433-446.

King, R. P., D. W. Lybecker, A. Regmi, and S. M. Swinton. 1993. Bioeconomic models of crop production systems: Design, development, and use. Rev. Agric. Econ. 15:393-405.

Korte, C. J., B. R. Whatkins, and W. Harris. 1984. Effects of the timing and intensity of Spring grazing on reproductive development, tillering and herbage production on perennial ryegrass dominated pastures. NZ J. Agric. Res. 27:135-149.

Lien, G., and B. J. Hardaker. 2001. Whole-farm planning under uncertainty: Impacts of subsidy scheme and utility function on portfolio choice in Norwegian agriculture. European Rev. Agric. Econ. 28(1):17-36

McCall, D. G. 1993. Approaches to systems research in the development of dairy grazing systems. Page 16 in Technical Workshop: Parallels in Dairy Grazing in New Zealand and the Midwest. University of Wisconsin, Madison.

McCall, D. G., and D. A. Clark. 1999. Optimised dairy grazing systems in the Northeast United States and New Zealand. II. System analysis. J. Dairy Sci. 82:1808-1816.

McCall, D. G., D. A. Clark, L. J. Stachurski, J. W. Penno, A. M. Byrant, and B. J. Ridler. 1999. Optimised dairy grazing systems in the Northeast United States and New Zealand. 1. Model Description and Evaluation. J. Dairy Sci. 82:1795-1807.

McKone, T. E. 1996. Overview of the risk analysis approach and terminology: The merging of science, judgment and values. Food Contr. 7(2):69-76.

Milham, N. 1992. Financial structure and risk management of woolgrowing farms: A dynamic stochastic budgeting approach. MEc dissertation, University of New England, Armidale.

Milham, N. 1998. Analyzing drought strategies to enhance farm financial viability. Technical report on the practice of whole-farm stochastic budgeting. NSW Agric. Project UNE 17, Austria.

Milham, N., and J. B. Hardaker. 1990. Financial management in Australian agriculture in the 1990s. In 17th Natl. Conf. Austra- 
lian Farm Manage. Soc. VCAH, Longerenong Campus, Dooen, Austria.

Neal, H. D., and J. H. M. Thornley. 1983. The lactation curve in cattle: A mathematical model of the mammary gland. J. Agric. Sci. 101:389-400.

O'Donovan, M. 2000. The relationship between the performance of dairy cows and grassland management on intensive dairy farms in Ireland. Ph.D.dissertation, University College, Dublin, Ireland.

O'Donovan, M., P. Dillon, M. Rath, and G. Stakelum. 2002. A comparison of four methods of herbage mass estimation. Ir. J. Agric. Res. 41:17-27.

O'Mahony, S. F. 1992. Analysis of strategies for small dairy producers in Ireland, under changing milk quota and price regimes. M.Sc. Thesis, National University of Ireland, Dublin.

O’Mara, F. 1996. A net energy system for cattle and sheep. Dep. Anim. Sci. Prod., Faculty of Agriculture, University College Dublin, Belfield, Dublin.

O'Sullivan, M., and H. O'Neill. 2002. The Irish Farmer's Handbook. Middlethird Publishing Ltd., Middlethird, Ireland.

Palisade.2000. @Risk advanced risk analysis for spreadsheets. Palisade Corporation 31 Decker Road Newfield, New York.

Parsons, A. J., E. L. Leafe, B. Collett, P. D. Penning, and J. Lewis. 1983. The physiology of grass production under grazing. 2. Photosynthesis, crop growth and animal intake of continuously grazed swards. J. Appl. Ecol. 20:127-139.

Petersen, B. J. 2000. Probabilistic modeling: Theory and practice. Additives and Contaminants 17(7):591-599.

Petersen, B. J., and L. Barraj. 1996. Assessing the intake of contaminants and nutrients: A review of methods. J. Food Comp. Anal. 9:243-254.
Phillips, C. V. 2000. Applying fully articulated distributions. Am. J. Epidemiol. 151:S41. (Abstr.)

Phillips, C. V., and G. M. Maldonado. 1999. Using Monte Carlo methods to quantify multiple sources of error in studies. Am. J. Epidemiol. 149:S17. (Abstr.)

Richardson, J. W., and C. J. Nixon. 1986. Description of FLIPSIM V: A general firm level policy simulation model. Texas Agric. Exp. Stn. Bull. B-1528.

Rotz, C. A., D. R. Buckmaster, D. R. Mertens, and J. R. Black. 1989 DAFOSYM: A dairy forage system model for evaluating the alternatives in forage conservation. J. Dairy Sci. 72:3050-3063.

Sørensen, J. T. 1990. Validation of livestock herd simulation models: A review. Livest. Prod. Sci. 26:79-90.

Stakelum, G. 1991. The production and utilisation of grass for grazing and silage. Ir. Grassl. Anim. Prod. Assoc. J. 25:3-37.

Swinton, S. C., and J. R. Black. 2000. Modeling of agricultural systems. Dep. Agric. Econ., Michigan State University, East Lansing, MI.

Teagasc. 2002. Management Data for Farm Planning, Teagasc, Dublin, Ireland.

Teagasc. 2001. Nutrient and Trace Element Advice for Grassland and Tillage Crops. Teagasc, Dublin, Ireland.

Thomas, C. V., M. A. DeLorenzo, D. R. Bray, R. N. Weldon, R. A. Bucklin, and J. G. Martin. 1997. A stochastic economic analysis of large herringbone and parallel milking parlors. J. Dairy Sci. 80:2418-2428.

Veerkamp, R. F., P. Dillon, E. Kelly, A. R. Cromie, and A. F. Groen 2002. Dairy cattle breeding objectives combining yield, survival and calving interval for pasture based systems in Ireland under different milk quota scenarios. Livest. Prod. Sci. 76:137-151. 